\title{
Involvement of ras activation in toxic hair cell damage of the mammalian cochlea
}

\author{
Battaglia, A ; Pak, K ; Brors, D ; Bodmer, D ; Frangos, J A ; Ryan, A F
}

\begin{abstract}
To identify possible intracellular mediators of hair cell (HC) death due to ototoxins, we treated basal-turn, neonatal, rat HCs in vitro with several intracellular signaling inhibitors, prior to and during gentamicin exposure. The general guanine nucleotide-binding protein (G-protein) inhibitor, GDP-betaS $(1 \mathrm{mM})$, provided potent $\mathrm{HC}$ protection, suggesting involvement of G-proteins in the intracellular pathway linking gentamicin exposure to $\mathrm{HC}$ death. ADP-betaS had minimal effect, indicating that the protection is specific to guanosine diphosphate (GDP)-binding, rather than a general reaction to nucleotides. AzidoGTP(32) photolabeling and gel electrophoresis indicated activation of an approximately $21 \mathrm{kDa}$ G-protein in HCs after exposure to gentamicin. Spectroscopic analysis of peptide fragments from this band matched its sequence with H-Ras. The Ras inhibitors B581 (50 microM) and FTI-277 (10 microM) provided potent protection against damage and reduced c-Jun activation in HC nuclei, suggesting that activation of Ras is functionally involved in damage to these cells due to gentamicin.
\end{abstract}

DOI: https://doi.org/10.1016/j.neuroscience.2003.08.041

Posted at the Zurich Open Repository and Archive, University of Zurich

ZORA URL: https://doi.org/10.5167/uzh-8424

Journal Article

Originally published at:

Battaglia, A; Pak, K; Brors, D; Bodmer, D; Frangos, J A; Ryan, A F (2003). Involvement of ras activation in toxic hair cell damage of the mammalian cochlea. Neuroscience, 122(4):1025-1035.

DOI: https://doi.org/10.1016/j.neuroscience.2003.08.041 


\section{INVOLVEMENT OF RAS ACTIVATION IN TOXIC HAIR CELL DAMAGE OF THE MAMMALIAN COCHLEA}

\author{
A. BATTAGLIA, ${ }^{a}$ K. PAK, ${ }^{a}$ D. BRORS, ${ }^{a}$ D. BODMER, ${ }^{a}$ \\ J. A. FRANGOS ${ }^{b}$ AND A. F. RYAN ${ }^{a *}$ \\ ${ }^{a}$ Department of Surgery, Otolaryngology Division, University of Cali- \\ fornia, San Diego, School of Medicine, 9500 Gilman Drive 0666, La \\ Jolla, CA, 92093-0666, USA \\ ${ }^{b}$ Department of Bioengineering, University of California, San Diego, \\ Jacobs School of Engineering, 9500 Gilman Drive, La Jolla, CA, \\ 92093-0412, USA
}

\begin{abstract}
To identify possible intracellular mediators of hair cell (HC) death due to ototoxins, we treated basal-turn, neonatal, rat $\mathrm{HCs}$ in vitro with several intracellular signaling inhibitors, prior to and during gentamicin exposure. The general guanine nucleotide-binding protein (G-protein) inhibitor,

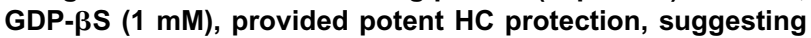
involvement of G-proteins in the intracellular pathway linking gentamicin exposure to HC death. ADP- $\beta S$ had minimal effect, indicating that the protection is specific to guanosine diphosphate (GDP)-binding, rather than a general reaction to nucleotides. Azido-GTP ${ }^{32}$ photolabeling and gel electrophoresis indicated activation of an approximately $21 \mathrm{kDa}$ G-protein in HCs after exposure to gentamicin. Spectroscopic analysis of peptide fragments from this band matched its sequence with H-Ras. The Ras inhibitors B581 (50 $\mu \mathrm{M})$ and FTI-277 $(10 \mu \mathrm{M})$ provided potent protection against damage and reduced c-Jun activation in HC nuclei, suggesting that activation of Ras is functionally involved in damage to these cells due to gentamicin. ( 2003 IBRO. Published by Elsevier Ltd. All rights reserved.
\end{abstract}

Key words: FTl-277, inner ear, gentamicin, G-protein, c-Jun phosphorylation, signal transduction.

Significant hearing loss occurs in about $10 \%$ of the population, and in its severe form can produce devastating isolation. In contrast to conductive hearing loss, which is produced by pathologies in the external and/or middle ear,

*Corresponding author. Tel: +1-858-534-4594; fax: +1-858-5345319.

E-mail address: afryan@ucsd.edu (A. F. Ryan).

Abbreviations: ADP, adenosine diphosphate; CDC-42, cell division cycle protein-42; DHB, 2,5-dihydroxybenzoic acid; DMEM, Dulbecco's Modified Eagle's medium; DTT, dithiothreitol; ERK, extra cellular regulated kinase; FBS, fetal bovine serum; Ftase, farnesyl-transferase; G-proteins, guanine nucleotide-binding proteins; GDP, guanosine diphosphate; GTP, guanosine triphosphate; HC, hair cell; IHCs, inner hair cells; IMAC, immobilized metal $\left(\mathrm{Fe}^{+3}\right.$ or $\left.\mathrm{Al}^{+3}\right)$ affinity chromatography; JNK, c-Jun-N-terminal kinases; MALDI, matrix-assisted laser desorption ionization; MAPKs, mitogen activated group of protein kinases; MEK, MAP Erk kinase; MEKK, MEK kinase; MKK, MAPK kinase; OC, organ of Corti; OHCs, outer hair cells; PBS, phosphate-buffered saline; $\left[\gamma^{32} \mathrm{P}\right] \mathrm{GTP}-\gamma \mathrm{AA}$, guanosine $5^{\prime}-\left[\gamma^{32} \mathrm{P}\right]$ triphosphate $[\gamma]$ 4-azidoanilide; Ras, retrovirus associated DNA sequence; Rho, Ras related homolog; SDS-PAGE, sodium dodecyl sulfate-polyacrylamide gel electrophoresis; SNHL, sensorineural hearing loss; U0126, 1,4-diamino-2,3-dicyano-1,4-bis-[2-aminophenylthio]butadiene. sensorineural hearing loss ( $\mathrm{SNHL}$ ) is associated with damage to cochlear hair cells (HCs) or neurons. Because HCs are the most vulnerable elements in the cochlea, damage to them underlies most forms of SNHL.

SNHL can result from a variety of causes, including genetic disorders, infectious disease, overexposure to intense sound and certain drugs. The most prevalent cause of SNHL is aging. SNHL is often progressive, and mostly irreversible. During the past several years, significant progress in understanding SNHL has been made (see Ding et al., 1999; Shulman, 1999; Ryan, 2000 for reviews). Oxidative stress with the production of free radicals (Schacht, 1999; Sha et al., 2001), activation of stress pathways (Pirvola et al., 2000) and apoptosis (Huang et al., 2000), have been implicated in $\mathrm{HC}$ damage and death.

Recently it has been demonstrated that c-Jun-N-terminal kinases (JNK) are activated in HCs after gentamicin exposure and that an inhibitor of mixed-lineage kinase, upstream activators of JNKs, protected HCs from toxicity (Pirvola et al., 2000). The JNKs are a member of the mitogen-activated group of protein kinases (MAPKs) that are important signal transducing enzymes involved in many facets of cellular regulation including apoptosis (Chang and Karin, 2001). However, intracellular signals that lead to JNK activation in HCs have yet to be defined.

Among the elements leading to JNK activation in other cells are the guanine nucleotide-binding proteins (G-proteins). For example, activation of Ras in certain cell types has been shown to be sufficient to activate JNK (Rausch and Marshall, 1997). Members of the Rho family including Rho, Rac and Cdc42 have also been implicated in JNK activation (Bagrodia et al., 1995; Minden et al., 1995). In addition, direct activation of G-proteins by free radicals has been described in other cell systems (Perez-Sala and Rebollo, 1999) and there are substantial data linking Gproteins with apoptosis (Mayo et al., 1997). In this study we addressed the role of GTPases in gentamicin-induced toxicity signaling.

\section{EXPERIMENTAL PROCEDURES}

\section{Tissue culture}

Explants of sensory epithelium from the basal cochlear turn of postnatal day 5 (p5) Sprague-Dawley rats were isolated using the methods of Van De Water and Sobkowicz (Van de Water and Ruben, 1974; Sobkowicz et al., 1993). Explants were maintained in Dulbecco's Modified Eagle's medium (DMEM) with $10 \%$ fetal bovine serum (FBS) and $30 \mathrm{U} / \mathrm{ml}$ penicillin, to which HEPES buffer had been added to a concentration of $25 \mathrm{mM}$ to stabilize $\mathrm{pH}$ and the glucose concentration increased to $6 \mathrm{mg} / \mathrm{ml}$ to enhance neuronal survival (Gibco, BRL, Grand Island, NY, USA). Each $15 \mathrm{~mm}$ 
dish containing $250 \mu$ l of medium was maintained in an incubator at $37{ }^{\circ} \mathrm{C}$ with $5 \% \quad \mathrm{CO}_{2}$ and $95 \%$ humidity. Gentamicin alone cultures were maintained in this initial medium for $12-24 \mathrm{~h}$ and then exposed to medium containing $35 \mu \mathrm{M}$ gentamicin (Sigma, St. Louis, MO, USA) for $48 \mathrm{~h}$. This concentration has been found to result in approximately $50 \%$ loss of outer $\mathrm{HCs}(\mathrm{OHCs})$, and was used to permit increases or decreases in $\mathrm{OHC}$ damage to be detected. For all inhibitor studies, cultures were maintained overnight $(12 \mathrm{~h})$ with a test substance. This was to permit the substance to penetrate the $\mathrm{HC}$ membrane. They were then challenged with medium containing $35 \mu \mathrm{M}$ gentamicin plus the test substance for an additional $48 \mathrm{~h}$, followed by fixation and evaluation. The doses of test substances (Cal-Biochem, San Diego, CA, USA; Sigma) employed were based on published $50 \%$ inhibitory concentrations $\left(\mathrm{IC}_{50}\right)$ in other whole-cell systems: the farnesyl-transferase (Ftase)-1-inhibitor B581 $(5,50 \mu \mathrm{M})$; the more specific and cell-permeable Ftase inhibitor FTI-277 (1, 2, 5, 10, $25 \mu \mathrm{M})$; GDP- $\beta$ S and ADP- $\beta S$ ( $1 \mu \mathrm{M}$; Lerner et al., 1995; Ui et al., 1995; Burke et al., 1996; Slee et al., 1996; Leonard, 1997; Eyers et al., 1998; Humpf et al., 1998; Newton et al., 2000). GDP- $\beta S$, a competitive inhibitor of GTP, and ADP- $\beta S$, a structurally similar molecule that does not interact with GTP bindings sites, are known to have low but similar permeabilities in intact cells after 3-4 h (Kuchan et al., 1994). U0126 (1,4-diamino-2,3-dicyano-1,4bis[2-aminophenylthio]butadiene) is cell permeable and a very specific MEK inhibitor at micromolar concentrations. U0126 (IC ${ }_{50}$ approximately $1.0 \mu \mathrm{M}$ ) has been shown not to inhibit protein kinase C, Raf, MEKK, ERK, JNK, MKK3, 4, and 6, and Cdk2 and 4 (Alessi et al., 1995; Newton et al., 2000). U0126 was used at $1 \mu \mathrm{M}$. We and others have shown this concentration to be nontoxic to many cell types (e.g. Alessi et al., 1995; Newton et al., 2000; Aletsee et al., 2001; Palacios et al., 2002). U0124 is a structurally similar but inactive compound that is often used as a control for U0126. The highest dose of each inhibitor used was used in combination with $50 \mu \mathrm{M}$ gentamicin on E. coli cultures, as a control for physical interaction with the antibiotic. None had any effect on bactericidal activity (data not shown).

\section{Phalloidin assays}

At the end of culture, the free-floating explants were fixed with $4 \%$ paraformaldehyde and $1 \%$ glutaraldehyde in phosphate-buffered saline (PBS) for $45 \mathrm{~min}$ at $20^{\circ} \mathrm{C}$, then permeablized with $1 \%$ Tween 20 (polyoxyethylene sorbitan monolaurate) in PBS at $20^{\circ} \mathrm{C}$ for $30 \mathrm{~min}$. The explants were then stained with a conjugated phalloidin-rhodamine probe in PBS at $20^{\circ} \mathrm{C}$ for $45 \mathrm{~min}$, washed twice with PBS and mounted between two coverslips in a 1:3 mixture of PBS/glycerol. Phalloidin-rhodamine stains the F-actin of the stereocilia and cuticular plate of viable HCs (Thorne et al., 1987). It also lightly outlines the body of HCs by binding to the actin that is associated with the inner surface of the cell membrane (Thorne et al., 1987). Because one of the earliest signs of morphologic injury is damage to stereocilia, it is readily detected by phalloidin staining. Subsequent apical vacuolization, swelling of the $\mathrm{HC}$, damage to the cuticular plate and finally $\mathrm{HC}$ death can also be observed (Raphael et al., 1994). The phalloidin assay has been widely used to assess the integrity of HCs (Meiteles and Raphael, 1994; Raphael et al., 1994). Explants were imaged by light and fluorescence microscopy and by laser confocal microscopy.

\section{Assessment of HC survival}

HCs were characterized as missing if no stereocilia or cuticular plate in the appropriate location was observed. Quantitative results were obtained by evaluating the thirty $\mathrm{OHCs}$ associated with 10 inner HCs (IHCs) in a given microscope field. The average of four separate counts was used to represent each culture and only those cultures for which four separate counts could be obtained were included in the study. Six cultures were used for each condition tested.

\section{Phospho-c-Jun immunhistochemistry}

The basal turn of the organ of Corti (OC) was dissected and cultured as described above. Gentamicin alone explants were exposed to $35 \mu \mathrm{M}$ gentamicin for $20 \mathrm{~h}$. Experimental cultures were pretreated with FTI-277 $(35 \mu \mathrm{M})$ for $12 \mathrm{~h}$, then with gentamicin and FTI-277 for $20 \mathrm{~h}$. Normal control explants were maintained in culture medium alone. FTI-277 alone explants were maintained in culture media containing $10 \mu \mathrm{M} \mathrm{FTI-277}$ alone. At the end of the culturing period, the explants were fixed as described above, permeabilized with $5 \%$ Triton X-100 in PBS with $10 \%$ FBS for 30 min. The explants were washed twice with PBS and incubated in $1 \%$ donkey serum, then immunostained with a polyclonal rabbit anti-phospho-c-Jun antibody (Ser-73; 1:50; Cell-Signaling). The explants were washed twice with PBS, and incubated with a FITC conjugated donkey anti-rabbit IgG (1:100; Jackson Immunoresearch, Bar Harbor, ME, USA) for $2.5 \mathrm{~h}$, washed twice with PBS and stained with the conjugated phalloidin-rhodamine probe for $1 \mathrm{~h}$, washed twice in PBS and visualized on a fluorescent microscope with either red filter (for the phalloidin-rhodamine staining, excitation/emission wavelength $596 \mathrm{~nm} / 615 \mathrm{~nm}$ ) or green filter (for the FITC staining, excitation/emission wavelength $490 \mathrm{~nm} /$ $525 \mathrm{~nm}$ ). The primary antibody was replaced with PBS as a control for non-specific binding.

\section{G-protein photoaffinity labeling, isolation and sequence analysis}

To determine whether ototoxins activate G-proteins, photoaffinity labeling using a hydrolysis-resistant, photoaffinity GTP azido-analog, guanosine $5^{\prime}-\left[\gamma^{32} \mathrm{P}\right]$ triphosphate $[\gamma]$ 4-azidoanilide $\left(\left[\gamma^{32} \mathrm{P}\right] \mathrm{GTP}-\gamma \mathrm{AA}\right)$ was employed. In photoaffinity G-protein labeling, a covalent linkage is created between the UV-sensitive, $\left[\gamma^{32}\right.$ P]GTP- $\gamma$ AA probe and activated G-proteins, in which the GTP analog occupies the GTP binding site. Thus, G-proteins that are activated after exposure to ototoxins in cells loaded with the $\left[\gamma^{32}\right.$ P]GTP- $\gamma$ AA probe can be irreversibly labeled and can subsequently be analyzed by sodium dodecyl sulfate-polyacrylamide gel electrophoresis (SDS-PAGE) and autoradiography (Basu and Modak, 1987). Once photolabeled, the proteins can also be purified through the use of immobilized metal $\left(\mathrm{Fe}^{+3}\right.$ or $\left.\mathrm{Al}^{+3}\right)$ affinity chromatography (IMAC). Immobilized $\mathrm{Fe}^{+3}$ or $\mathrm{Al}^{+3}$ selectively binds phosphorylated proteins, including the photolabeled proteins (Andersson and Porath, 1986). Once isolated, if sufficiently pure, the proteins can be digested and identified using matrixassisted laser desorption ionization (MALDI) time-of-flight mass spectrometry (Karas and Hillenkamp, 1988).

\section{G-protein photolabeling}

After incubation in serumless DMEM media for $1 \mathrm{~h}$, five basal-turn explants were permeabilized in the dark for $5 \mathrm{~min}$ at RT with $25 \mu \mathrm{M}$ digitonin in serumless media containing $10 \mu \mathrm{Ci}$ of $\left[\gamma^{32} \mathrm{P}\right] \mathrm{GTP}-\gamma \mathrm{AA}$ with a specific activity of $10-20 \mathrm{Ci} / \mathrm{mmol}$. In separate explants, cells were checked for viability 12,24 and $48 \mathrm{~h}$ after incubation with digitonin, using the $0.4 \%$ Trypan Blue exclusion method, and no loss of viability was observed (data not shown). The supernatant was then removed and replaced for selected times with serumless media containing the same concentration of the isotope at room temperature. In test groups, the replacement media also contained $35 \mu \mathrm{M}$ gentamicin. Explants were incubated for $5 \mathrm{~min}$ or $1 \mathrm{~h}$. The cultures were then exposed to hand-help UV light $(254 \mathrm{~nm})$ at a $2 \mathrm{~cm}$ distance for $2.5 \mathrm{~min}$. The supernatant was then replaced with ice cold $2 \mathrm{mM}$ dithiothreitol (DTT) in serumless media to terminate the reaction for $5 \mathrm{~min}$. The DTT solution was then replaced with Laemmli buffer and $10 \%$ 
SDS-PAGE was performed. After gel drying, autoradiography was performed (Jo et al., 1992). Photoactivity of the probe was confirmed by exposing the probe to serum GTP-binding protein and performing photolysis with a hand-held UV lamp. Negative controls were performed by treating explants for $48 \mathrm{~h}$ with $200 \mu \mathrm{M}$ gentamicin, thereby selectively killing $\mathrm{HCs}, 2$ days prior to a second 5 min gentamicin treatment and G-protein labeling. Positive controls were performed by treating cardiac fibroblasts with $1 \mu \mathrm{M}$ bradykinin for $5 \mathrm{~min}$, which activates an approximately $42 \mathrm{kD}$ $\mathrm{G}_{\alpha}$ subunit.

\section{Immobilized $\mathrm{Al}^{+3}$-chelate affinity chromatography}

Immobilized $\mathrm{Al}^{+3}$-chelate affinity chromatography was performed as described by Shoemaker and Haley (1993). Iminodiacetic acid Sepharose 6B fast flow resin (1-2 ml; Sigma) was placed in a $5 \mathrm{ml}$ syringe and washed with $10 \mathrm{ml}$ of distilled water. Ten milliliters of $50 \mathrm{mM} \mathrm{AlCl}{ }_{3}$ was then passed through the column and washed with $10-15 \mathrm{ml}$ of distilled water. The column was then equilibrated with $100 \mathrm{mM}$ ammonium acetate at $\mathrm{pH}$ 5.9. 40 basal turn explants previously photolabeled after treatment for $1 \mathrm{~h}$ with gentamicin were then homogenized in a small glass douncer containing $1 \mathrm{ml}$ $100 \mathrm{mM}$ ammonium acetate at $\mathrm{pH}$ 5.9. Negative controls contained explants treated only with serumless media. Homogenates were then passed through the charged resin column. The column was washed consecutively with $15 \mathrm{ml}$ of $100 \mathrm{mM}$ ammonium acetate at $\mathrm{pH} 5.9,5 \mathrm{ml}$ of $100 \mathrm{mM}$ ammonium acetate containing $0.5 \mathrm{M} \mathrm{NaCL}$ at $\mathrm{pH} 5.9$, and then $5 \mathrm{ml}$ of $100 \mathrm{mM}$ ammonium acetate at $\mathrm{pH}$ 5.9. Photolabeled proteins bound to the charged resin beads were then eluted with $5 \mathrm{ml}$ of $100 \mathrm{mM}$ ammonium acetate containing $10 \mathrm{mM} \mathrm{KH}_{2} \mathrm{PO}_{4}$ at $\mathrm{pH}$ 8.0. The purified, photolabeled peptides eluted in the phosphate wash were pooled and then precipitated with 1:1 $(500 \mu \mathrm{l})$ isopropanol and tRNA $(10 \mu \mathrm{g} /$ $\mathrm{ml}$ ) at $-20{ }^{\circ} \mathrm{C}$. After overnight precipitation and pelleting, the pellets were solubulized using $1 \times$ Tris-glycine sample buffer (Bio-Rad Laboratories, Chicago, IL, USA). Fifteen percent SDSPAGE was then performed using two parallel wells for the experimental group and one well for the appropriate negative and positive controls. Pre-stained standards (Bio-Rad Laboratories) were used as well. The region containing the labeled protein was then cut from one experimental lane using a stainless steel scalpel, and the protein extracted for MALDI analysis.

\section{MALDI mass spectrometry}

The gel piece was transferred to a $0.5 \mathrm{ml}$ Eppendorf tube. Distilled water $(0.4 \mathrm{ml})$ was added, the tube vortexed for $1 \mathrm{~min}$, and the liquid discarded. Digestion buffer $(25 \mathrm{mM}$ ammonium bicarbonate, $\mathrm{pH} 8$ ) was added, the mixture vortexed for $1 \mathrm{~min}$, and the liquid discarded. Modified sequence grade trypsin (0.5 $\mathrm{\mu g}$; Promega) dissolved in digestion buffer (Promega, Madison, WI, USA) was then added to cover the gel piece at a trypsin concentration of $0.1 \mu \mathrm{g} / \mu \mathrm{l}$ while minimizing evaporation of the digestion solution and $\mathrm{Na}^{+}$and $\mathrm{K}^{+}$salt precipitation. The gel piece was then incubated with agitation at $30{ }^{\circ} \mathrm{C}$ overnight. The supernatant was then transferred to a new Eppendorf tube using a gel loading pipet tip. The gel piece was then re-extracted using $60 \%$ acetonitrile $/ 0.01 \%$ TFA (enough to cover the piece) by agitating for $20 \mathrm{~min}$ at $30^{\circ} \mathrm{C}$. The extract was then combined with the previous supernatant. This was repeated twice, while keeping the volume as low as possible. The pooled supernatants were then dried to approximately $10 \mu$ l using a lyophilizer. The MALDI ion trap mass spectrometer is composed of an external MALDI ion source and a modified Finnigan ITMS electronics kit. Laser desorption/ionization was carried out at wavelength of $355 \mathrm{~nm}$ with 10 ns duration pulses. The matrix solution consisted of 2,5-dihydroxybenzoic acid (DHB) in 1:1 (v/v) $\mathrm{ACN} / \mathrm{H}_{2} \mathrm{O}(2 \times$ dilution of a saturated solution of $\mathrm{DHB}$ in 1:1 (v/v) $\left.\mathrm{ACN} / \mathrm{H}_{2} \mathrm{O}\right)$. The mass spectroscopy samples were prepared by mixing $1 \mu$ l of sample solution with $1 \mu \mathrm{l}$ of matrix solution. The instrument was mass calibrated once a week.

\section{Procedure for protein identification}

The peptide mixture produced by in-gel trypsin digestion of protein was analyzed directly by MALDI ion trap mass spectroscopy without further chromatographic separation or treatment. Trypsin peaks were used as internal standards to calibrate the mass spectrometer and enable high resolution spectrometry with an error of $0.5 \mathrm{kDa}$ mass units. After the mass spectroscopy peptide map was inspected, the mass units were entered and searched against predicted trypsin digest fragments of proteins in a mammalian protein database (Genbank, Oxford Molecular Group, Mountain Valley, CA, USA) using the program ProFound (Genomic Solutions, Lansing, MI, USA) with a tolerance of $0.2 \mathrm{kDa}$. Peaks that were not one third above background and those that matched the blank gel were not included. The search was carried out with constraints that include the mass range of the protein, the cleavage specificity of the digesting enzyme, and the originating species of the protein. A positive control sample containing $10 \mu \mathrm{g} / \mathrm{ml}$ of human Ras (Sigma) and a blank sample were analyzed as well.

\section{Data analysis}

Comparison of $\mathrm{HC}$ number after treatment with gentamicin and with different inhibitors was performed by using repeated measures ANOVA followed by LSD post hoc test (Stat View 5.0). Differences associated with $P$-values $<0.05$ were considered to be statistically significant. All data are presented as mean \pm S.E.

\section{RESULTS}

\section{In vitro ototoxicity}

Phalloidin-rhodamine-stained control explants showed the normal configuration of a single row of $\mathrm{IHCs}$ and three rows of OHCs in the area of the basal turn after $48 \mathrm{~h}$ in culture (Fig. 1a). All of the HCs exhibited normal stereociliary morphology. Equivalent basal turn explants treated with $35 \mu \mathrm{M}$ gentamicin for $48 \mathrm{~h}$ showed significantly reduced HC survival (Fig. 1b). The first row of OHCs showed the greatest degree of damage, followed by the second row of $\mathrm{OHCs}$ and then the third row. Total loss of OHCs was about $50 \%$. The $\mathrm{IHCs}$ were the most resistant to damage, showing only scattered loss.

\section{General G-protein inhibitor GDP-ßS protected auditory HCs}

Treatment of basal turn explants with the general G-protein inhibitor GDP- $\beta S$ ( $1 \mathrm{mM}$ ) for $12 \mathrm{~h}$ prior to gentamicin exposure and during exposure for $48 \mathrm{~h}$ to $35 \mu \mathrm{M}$ gentamicin resulted in a significant increase $(P<0.01)$ in the number of surviving OHCs as well as in the number of $\mathrm{HCs}$ that appeared morphologically normal compared with the group with gentamicin alone (Figs. 1c, 2a).

ADP- $\beta S$ did not protect the HCs against gentamicin toxicity ( $P=0.216$; data not shown). Explants treated for $48 \mathrm{~h}$ with $1 \mathrm{mM}$ GDP- $\beta S$ alone, also appeared normal (data not shown). 

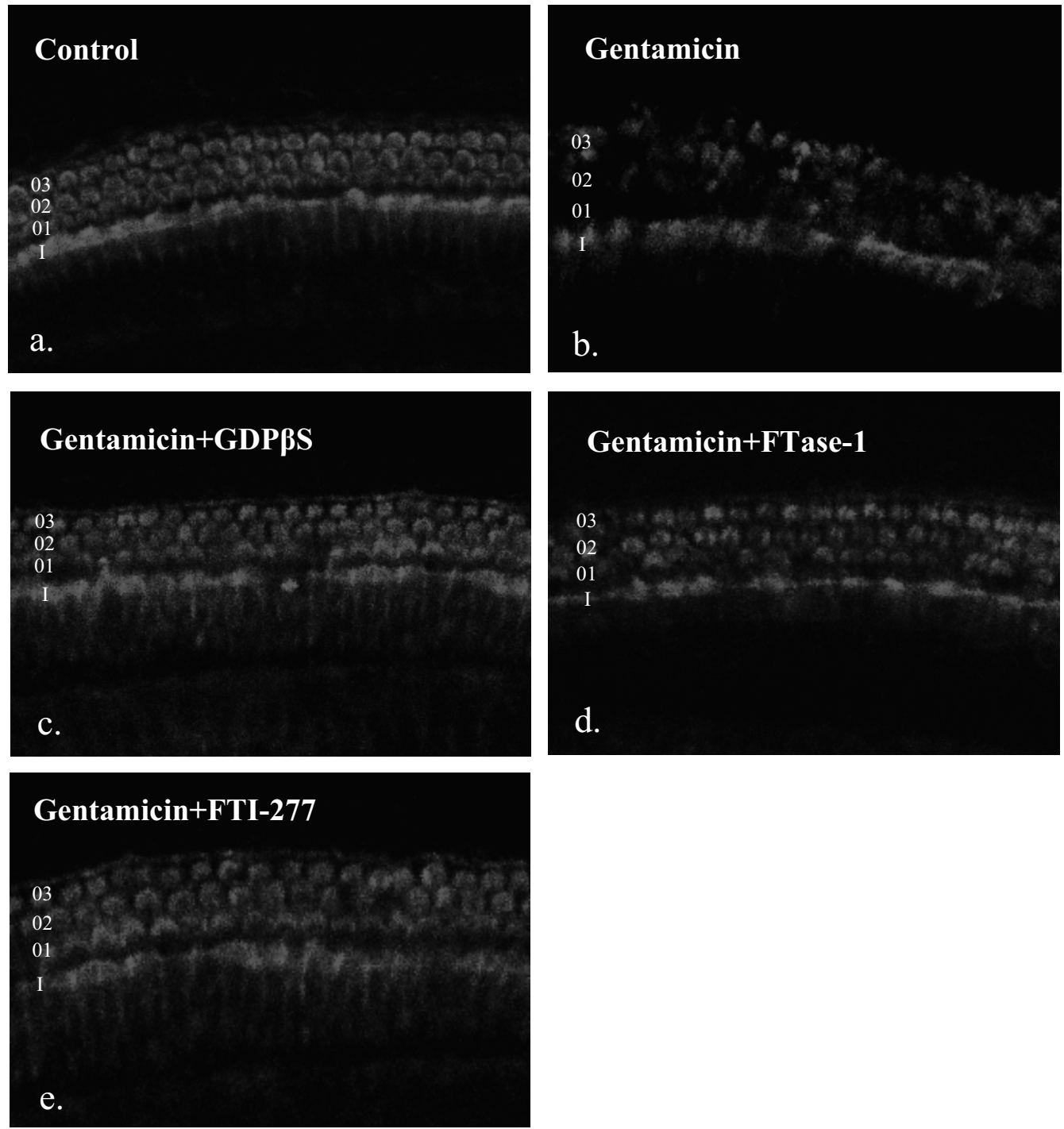

Fig. 1. a) Rhodamine-phalloidin staining of a cultured normal $p 5$ rat OC basal turn explant. Note intact stereocilia of OHCs and IHCs. The OHCs (1-3) are in the uppermost three rows while the IHCs (I) are in the lowermost row. b) Representative $\mathrm{p} 5 \mathrm{rat} \mathrm{OC}$ basal turn explant after $48 \mathrm{~h}$ in vitro exposure to gentamicin. Note the extensive loss of OHCs with the $\mathrm{IHCs}$ being the most resistant to damage and the third row of OHCs being the second most resistant. c) Representative explant treated with GDP- $\beta S(1 \mathrm{mM})$ prior to and during exposure to gentamicin $(35 \mu \mathrm{M})$ in vitro. There was a significant $(P<0.01)$ improvement in OHC survival compared with gentamicin alone. d) Explant treated with the Ftase-inhibitor B581 (50 $\mu \mathrm{M})$ prior to and during gentamicin exposure. Significant $(P<0.01)$ protection of OHCs was observed. e) Explant treated with the Ftase-inhibitor FTI-277 (10 $\mu$ M) prior to and during gentamicin exposure in vitro. Again, significant $(P<0.01) \mathrm{OHC}$ protection was observed.

\section{G-protein photoaffinity labeling in the OC after exposure to gentamicin}

To determine the molecular weight of G-proteins that might be activated by gentamicin, basal turn explants were loaded with $\left[\gamma^{32} \mathrm{P}\right] \mathrm{GTP}-\gamma \mathrm{AA}$ and then treated with gentamicin for $5 \mathrm{~min}$ or $1 \mathrm{~h}$ in the dark. After UV exposure, SDSPAGE and autoradiography revealed that one or more approximately $21 \mathrm{kDa}$ G-proteins were activated by gentamicin at both $5 \mathrm{~min}$ and $1 \mathrm{~h}$ (Fig. 3a). Negative controls revealed minimal photolabeling at $21 \mathrm{kDa}$ in explants exposed to ototoxin-free media (Fig. 3a). Cardiac fibroblasts treated with $1 \mu \mathrm{M}$ bradykinin for $5 \mathrm{~min}$ showed a approximately $42 \mathrm{kD}$ labeled protein (data not shown). Pre-incubation of OC sam- ples with $1 \mathrm{~m}$ GDP- $\beta S$ prevented incorporation of the probe, while ADP- $\beta S$ did not. Explants pre-treated with $200 \mu \mathrm{M}$ gentamicin for $48 \mathrm{~h}$ in order to specifically destroy $\mathrm{HCs}$ prior to photolabeling experiments showed little or no incorporation of the azido-GTP probe during a subsequent gentamicin exposure, suggesting that the observed $21 \mathrm{kDa}$ GTP binding is related to $\mathrm{HCs}$ (Fig. 3b).

\section{Isolation and purification of $\mathbf{2 1} \mathrm{kDa}$ band and MALDI analysis}

Basal turn explants were loaded with $\left[\gamma^{32} \mathrm{P}\right] \mathrm{GTP}-\gamma \mathrm{AA}$ as above and then treated with gentamicin for $1 \mathrm{~h}$ in the dark. After UV exposure, phosphorylated proteins were captured 
a.

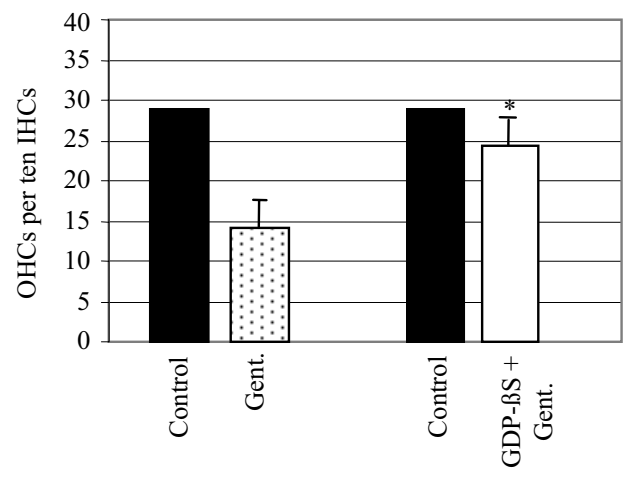

b.

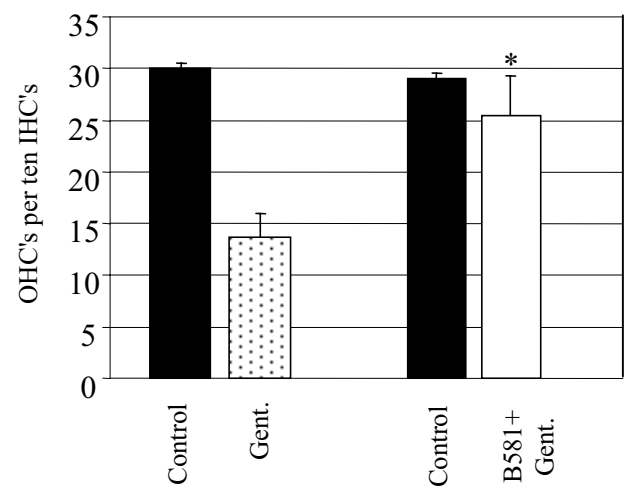

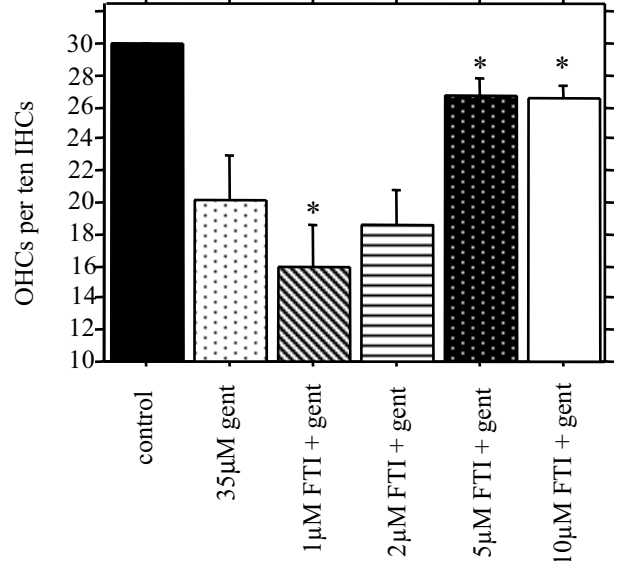

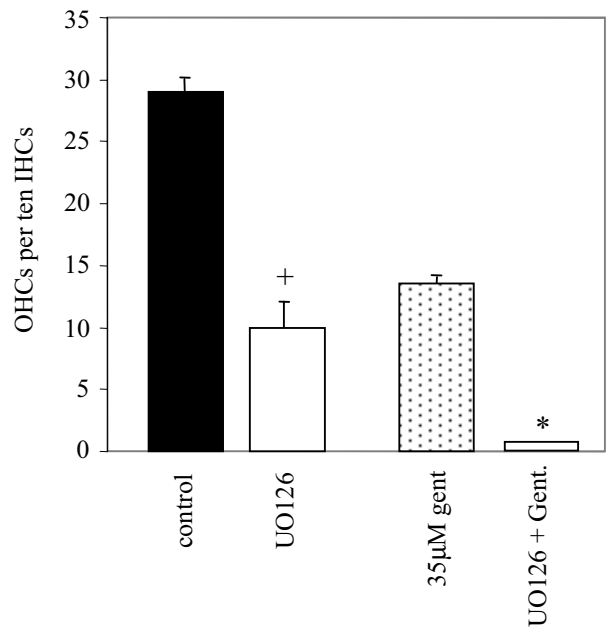

Fig. 2. a) Average OHC survival after exposure to gentamicin $(35 \mu \mathrm{m})$ in vitro, with or without $1 \mathrm{mM}$ GDP- $\beta S(P<0.01)$. Control cultures received no gentamicin or inhibitor. The data are expressed as the mean number of surviving OHCs per $10 \mathrm{IHCs}$. The control columns represent separate control groups for each experimental condition. Vertical lines represent S.E.M. The error bars were too small to be seen in the control groups (29.7 \pm 0.3 $\mathrm{OHCs} / 10 \mathrm{IHCs}$ ). * Indicates a significant difference from gentamicin alone. b) Average OHC survival after exposure to gentamicin, with or without B581 $(50 \mu \mathrm{m})$. The increase in survival induced by this inhibitor is significant $(P<0.01) .{ }^{*}$ Indicates a significant difference from gentamicin alone. $\left.\mathrm{C}\right)$ Average of OHC survival after exposure to gentamicin, with and without FTI-277 at the concentrations shown. $\mathrm{HC}$ survival is adversely affected at the lowest concentration $(1 \mu \mathrm{M} ; P<0.05)$ of $\mathrm{FTI}-277$ compared with gentamicin alone, whereas at the highest concentrations $(5,10 \mu \mathrm{M}) \mathrm{FTI}-277$ protected HCs from gentamicin toxicity $(P<0.01) .{ }^{*}$ Indicates a significant difference from gentamicin alone. d) Average basal turn OHC survival after exposure to gentamicin and/or the MEK inhibitor U0126 $(1 \mu \mathrm{M})$. There was a significant decrease in OHC survival after treatment with $\mathrm{U} 0126$ alone $(P<0.01)$, and also when comparing gentamicin and U0126 versus gentamicin $(P<0.01) .{ }^{+}$Indicates significant difference from control culture, ${ }^{*}$ indicates a significant difference from gentamicin alone.

by $\mathrm{Al}^{+3}$ IMAC and then eluted prior to resolution in two adjacent lanes by SDS-PAGE. Gel pieces were cut out in the 20-25 kDA range from one lane and trypsin digested prior to MALDI analysis. Autoradiography of the adjacent lane on the gel confirmed photolabeling of $21 \mathrm{kDa}$ GTP binding protein (Fig. 3c).

High resolution MALDI analysis of the trypsin digested sample revealed a peptide map dominated by several peaks. When the peak spectrum was used to search the protein database, the optimal match was with $\mathrm{c}-\mathrm{H}-\mathrm{Ras}-\mathrm{p} 21$, with $46 \%$ sequence coverage. The peptide peaks that matched c-H-p21-Ras produced a $z$ score of $1.66(P<0.05)$. MALDI of purified Ras positive control followed by database analysis showed the highest match to an H-Ras p21 protein mutant with GIn 61 replaced by Leu. The sequence coverage was $69 \%$ with a $z$ score of $2.38(P<0.05)$.

\section{The farnesyl-transferase inhibitors B581 and FTI-277 protect auditory HCs}

To determine the functional role of Ras activation in gentamicin-mediated $\mathrm{OHC}$ death, basal turn explants were pre-treated with $50 \mu \mathrm{M}$ B581 or $10 \mu \mathrm{M}$ FTI-277 for $12 \mathrm{~h}$ prior to exposure to gentamicin (in addition to the inhibitor). We observed a significant $(P<0.05)$ increase in $\mathrm{OHC}$ survival in explants treated with either inhibitor, compared with explants treated with gentamicin alone (Figs. 1d, e, 2b). In the case of FTI-277 we observed a dose-dependent effect in $\mathrm{OHC}$ survival (Fig. 2c). The lowest dose of FTI-277 $(1 \mu \mathrm{M})$ was associated with significantly more $\mathrm{OHC}$ loss than observed with gentamicin alone ( $P<0.01$; Fig. 2c). However, at the highest dosages (5 and $10 \mu \mathrm{M})$ significant $\mathrm{OHC}$ protection occurred $(P<0.01$; Fig. 2c). Explants 


\section{Gent Contr}

5' 60 '

60

a.

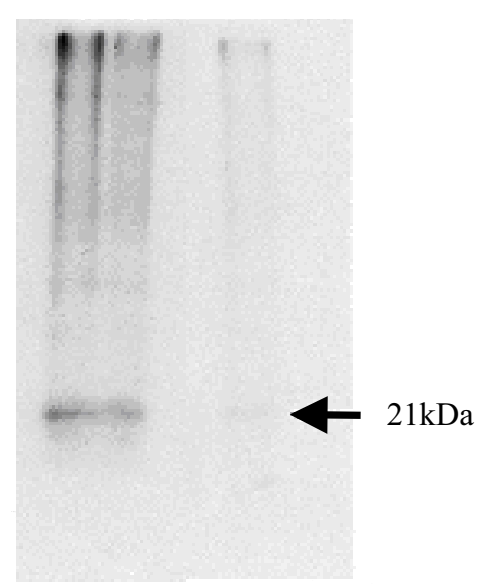

No

$\mathrm{OHCs} \mathrm{OHCs}$

$1 \quad 2 \quad 3$

b.

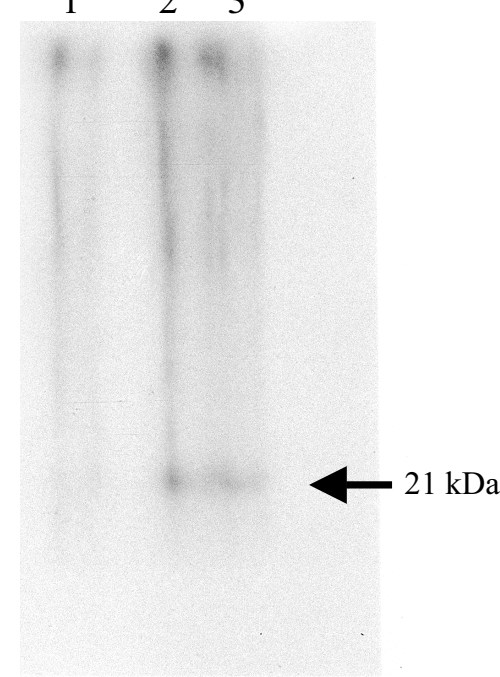

Contr Epi Gent

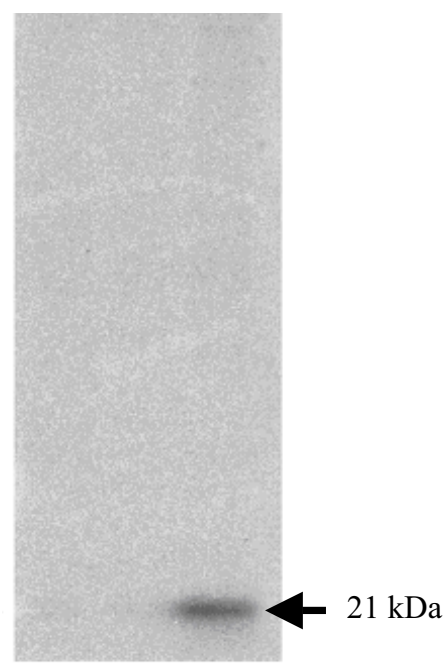

Fig. 3. a) Autoradiography of proteins from control $P 5$ rat $O C$ basal turn explants and explants treated with $35 \mu M$ gentamicin for 5 min or $1 \mathrm{~h}$. Explants were exposed to UV light to induce photochemical cross-linking of $\left[\gamma^{32} \mathrm{P}\right]$ GTP $\gamma$ AA to activated G-proteins prior to SDS-PAGE, which revealed a 21 $\mathrm{kDa}$ protein. Negative control explants maintained only in culture media for $1 \mathrm{~h}$ revealed minimal photolabeling at $21 \mathrm{kDa}$. b) Autoradiography of P5 rat OC explants exposed to gentamicin. Explants pre-treated with $200 \mu \mathrm{M}$ gentamicin for $48 \mathrm{~h}$ in order to specifically kill HCs and then allowed to recover for $48 \mathrm{~h}$ prior to a $5 \mathrm{~min}$ treatment with gentamicin and photolabeling showed minimal incorporation of the azido-GTP probe (lane 1). Normal explants (lanes 2, 3) showed GTP binding of $21 \mathrm{kDa}$ protein in response to gentamicin. c) Autoradiography of SDS-PAGE after Al ${ }^{+3}$ IMAC purification of proteins from OC explants. There is no protein labeling in the negative control explants or in explants treated with $1 \mu \mathrm{M}$ epinephrine. Proteins from explants treated with gentamicin showed strong labeling at $21 \mathrm{kDa}$. An identical lane was cut out and protein extracted for MALDI analysis.

treated with $10 \mu \mathrm{M} \mathrm{FTI-277} \mathrm{alone} \mathrm{were} \mathrm{normal} \mathrm{(data} \mathrm{not}$ shown).

\section{FTI-277 attenuates JNK signaling in ototoxicity}

To determine whether the protection of OHCs by Ras inhibition using FTI-277 was associated with an attenuation of the JNK signaling pathway, explants were either exposed to gentamicin or pretreated with $10 \mu \mathrm{M}$ FTI277 and then exposed to gentamicin plus FTI-277 for $20 \mathrm{~h}$ prior to phospho-c-Jun immuno-labeling. Control explants, exposed to culture medium alone, showed no detectable immunostaining of $\mathrm{HC}$ nuclei (Fig. 4b). Basal turn explants of the $\mathrm{OC}$ exposed to $35 \mu \mathrm{M}$ gentamicin for $20 \mathrm{~h}$ and immunostained showed strong phospho-c-Jun immunolabeling of $\mathrm{OHC}$ nuclei, and a lesser labeling of IHC nuclei (Fig. 4d). There was no labeling of supporting cell nuclei. Explants treated with FTI-277 prior to and during gentamicin treatment showed little or no immunostaining (Fig. 4f). Because of the reduced time of exposure to gentamicin, all explants when stained with phalloidin-rhodamine showed one row of IHCs and three rows of OHCs (Fig. 4a, c, e). 

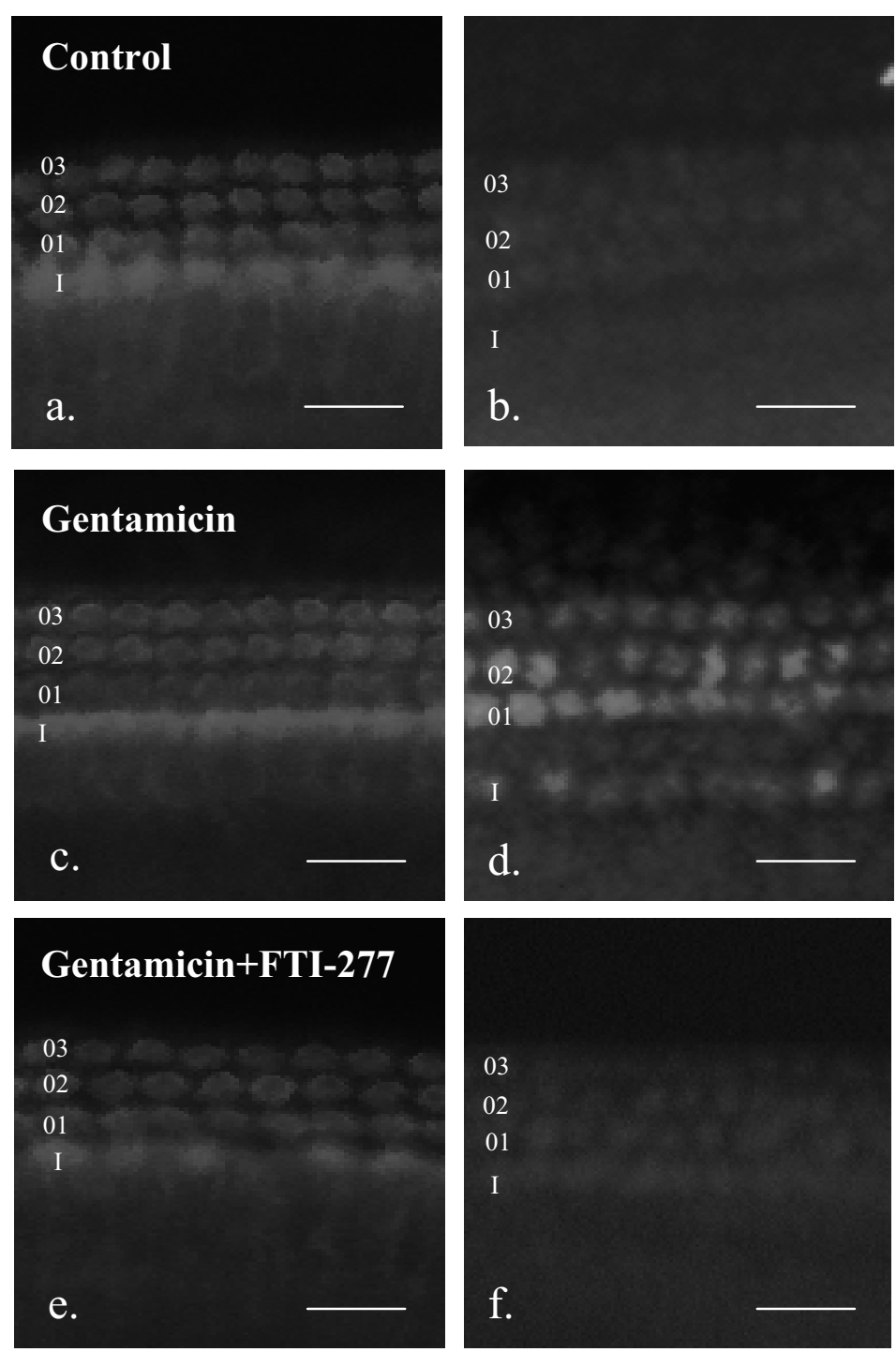

\section{Phalloidin}

\section{Phospho-c-Jun}

Fig. 4. a, b) Basal turn $\mathrm{p} 5 \mathrm{OC}$ explants maintained in culture medium alone (Control) for $32 \mathrm{~h}$ show the normal configuration of the $\mathrm{OC}$ in phalloidin labeled images (a), and no phospho-c-Jun immunolabeling (b). O1, O2, O3: row 1, 2, and 3 of OHCs, I: IHCs. Bar=20 $\mu \mathrm{m}$. c, d) Basal turn explant maintained in culture for $12 \mathrm{~h}$ and then exposed to $35 \mu \mathrm{M}$ gentamicin for $20 \mathrm{~h}$ shows normal morphology in the phalloidin-labeled image (c), and strong staining of the $\mathrm{OHC}$ nuclei and weaker labeling of IHC nuclei by the phospho-c-Jun antibody (d). Bar $=20 \mu \mathrm{m}$. e, f) Basal turn explant pretreated with FTI-277 $(10 \mu \mathrm{M})$ for $12 \mathrm{~h}$ and FTI-277 plus gentamicin $(35 \mu \mathrm{M})$ for $20 \mathrm{~h}$ shows normal OC in the phalloidin-rhodamine image (e), and little or no phospho-c-Jun immunolabeling (f). Bar $=20 \mu \mathrm{m}$.

\section{Auditory HCs and MEK: studies with U0126}

To determine whether Ras signaling via MEK and the ERK MAPK played a role in $\mathrm{OHC}$ toxicity, basal turn explants were exposed to gentamicin with or without a MEK inhibitor. Inhibitor control explants were exposed to the MEK inhibitor alone. Treatment of basal turn explants with the MEK inhibitor UO126 alone resulted in significant $(P<0.05) \mathrm{OHC}$ loss (Fig. $2 d)$. When gentamicin was added, both OHCs and IHCs were completely lost $(P<0.001$; Fig. $2 d)$. The control compound U0124 had no effect on normal or gentamicin-treated OC (data not shown).

\section{DISCUSSION}

We have previously shown that the growth factor FGF-2, whose receptor often activates G-proteins, protects $\mathrm{OHCs}$ against ototoxins (Low et al., 1996). As a preparatory step in assessing the role of G-proteins in this protection, we treated basal turn $O C$ explants with a general G-protein inhibitor prior to and during gentamicin exposure. Against our expectations, explants treated with GDP- $\beta$ S revealed significantly improved $\mathrm{HC}$ survival, even in the absence of FGF-2, suggesting that inhibition of $G$ protein activity itself can protect $\mathrm{HCs}$ from this toxin. 
Intracellular GDP- $\beta$ S presumably inactivates G-proteins which would otherwise initiate cell death after exposure to gentamicin. The fact that ADP- $\beta S$, a structural analog of GDP- $\beta S$ with similar charge, did not significantly improve HC survival after gentamicin exposure supports the interpretation that GDP- $\beta$ S acts through intracellular inhibition of G-protein activity as opposed to extracellular neutralization of the toxin or a nonspecific intracellular activity of nucleotides. [ $\left.\gamma{ }^{32} \mathrm{P}\right] \mathrm{GTP} \gamma \mathrm{AA}$ photolabeling studies indicated that, relative to untreated explants, gentamicin-treated explants exhibit increased GTP binding activity by proteins in the $21 \mathrm{kDa}$ range, such as members of the Ras or Rho families.

Exposure to stressful stimuli induces small G-protein activation in other cell systems. Interestingly, this activation can be either protective or damaging depending upon, for one thing, the length of stress application. For example, 5-10 min of exposure to free radicals in Jurkat T-cells has been shown to induce Ras activation directly by redox modification of amino acid residue Cys ${ }^{118}$ (Lander et al., 1997) which in turn results in Ras binding to the effector PI3K (Deora et al., 1998). The serine-threonine kinase Akt/PKB can subsequently be activated leading to increased BAD phosphorylation, resulting in initial protection of the cell (Basu et al., 1998; Joneson and Bar-Sagi, 1999). Longer term exposure to stress has been shown to initiate cellular damage via small G-protein activation and the JNK pathway (Kharbanda et al., 2000). For example, Cos-7 cells transfected with dominant negative Ras are protected from apoptosis induced by long-term exposure to ceramide (Basu et al., 1998).

The results of MALDI and peptide matching indicated that $\mathrm{H}$-Ras is activated in the OC after brief toxin exposure. Other isoforms of Ras in addition to members of the Rho family do not appear to be activated at this early time, according to the MALDI analysis. The potential role of this Ras activation in $\mathrm{HC}$ toxicity was explored with Ftase inhibitors.

Ftase inhibitors block the activity of Ras by inhibiting the prenylation that is required for membrane insertion of Ras, which is in turn necessary for downstream Ras signaling (see Leonard, 1997 for a review). Within the Ras superfamily, Ftase inhibition is specific to Ras proteins, since Rho isoforms (with the exception of RhoB) and Rac are geranylgeranylated rather than farnesylated. FTI-277 does not affect geranylgeranylation at concentrations up to at least $10 \mu \mathrm{M}$, the highest dose used in the present study, suggesting that the effects of Ftase inhibitors within the Ras superfamily are limited to Ras isoforms. However, it should be noted that in addition to Ras, other proteins such as lamin B, $\gamma$-transducin, RhoB, and CENPs are also farnesylated. It is therefore possible that inhibition of these proteins is responsible for the protection of HCs from gentamicin. The lack of prior data linking them to $\mathrm{HCs}$ or to ototoxicity makes this less likely.

Interestingly, a dose response study of HCs to FTI-277 showed that HC survival is adversely affected at low concentrations $(1 \mu \mathrm{M})$ of this reagent, but that protection occurs at higher dosages $(5-10 \mu \mathrm{M})$. This suggests that Ras pathways contributing to $\mathrm{HC}$ survival are selectively inhibited at lower concentrations while Ras-dependent pathways contributing to $\mathrm{HC}$ death are selectively inhibited at higher concentrations $(10 \mu \mathrm{M})$. Potentially relevant to this issue, FTI-277 has been shown to have a dose-dependent specificity for the different Ras isoforms, H-Ras, N-Ras and K-Ras. H-Ras processing is inhibited at concentrations as low as $10 \mathrm{nM}$ of FTI-277 and is almost completely blocked at $3 \mu \mathrm{M}$ (Casey et al., 1989; Lerner et al., 1995). Inhibition of N-Ras processing requires $5 \mu \mathrm{M}$ of $\mathrm{FTI}-277$ while complete inhibition of K-Ras requires $10 \mu \mathrm{M}$ (Casey et al., 1989; Lerner et al., 1995). Thus, the data from our dose-response study suggest that low concentrations of FTI-277 may enhance OHC death through inhibition of $\mathrm{H}$-Ras, while higher concentrations of $\mathrm{FTI}-277$ may protect $\mathrm{OHCs}$ through inhibition of K-Ras and/or N-Ras.

This concept is supported by mounting data in the literature which indicate that the different Ras isoforms generate specific functional endpoints (Wolfman, 2001). Disruption of the gene encoding K-Ras results in a lethal embryonic phenotype while $\mathrm{H}$-Ras and N-Ras knockouts are viable, indicating significant differences between the isoforms in regulating development (Umanoff et al., 1995; Johnson et al., 1997; Koera et al., 1997; Esteban et al., 2001). $\mathrm{H}$-Ras is frequently involved in MEK/ERK activation via Raf 1. K-Ras appears to be more involved in Rac activation than the other isoforms. Overexpression of $\mathrm{K}$ Ras increases Rac/cdc42 accumulation, which in turn leads to more membrane ruffling and faster cell migration when compared with cells transfected with G12V-H-Ras (Walsh and Bar-Sagi, 2001). N-Ras appears to provide steady-state survival signals through $\mathrm{PI} 3 \mathrm{~K}$, Akt and mitochondrial Bcl-2 family proteins (Wolfman and Wolfman, 2000).

We found that MEK inhibitors also influenced $\mathrm{HC}$ survival, proving to be toxic to $\mathrm{OHCs}$ even without gentamicin. When they were used in combination with gentamicin, strong potentiation of toxicity was observed, and all $\mathrm{OHCs}$ and IHCs were lost. This suggests that normal OHCs and IHCs depend upon MEK activation for survival, and that MEK activity opposes cell death during toxin treatment. Ras is often an upstream activator of MEK, suggesting the Ras/Raf/MEK/ERK MAPK pathway. However, the observation that the MEK inhibitor alone but not FTI-277 alone is toxic to OHCs indicates that there may be other upstream activators of MEK such as protein kinase C, Rap1 or RafB (via crkL and C3G) that act independently of Ras (McCubrey et al., 2000) in normal HCs. In damaged HCs, H-Ras may contribute to MEK activation as it does in other cell types (Yamamoto et al., 1999).

With respect to $\mathrm{HC}$ damage, we recently observed inhibition of gentamicin-induced $\mathrm{HC}$ damage with Clostridium difficile toxin $\mathrm{B}$, a potent inhibitor of Rho GTPases including Rac/cdc42 (Bodmer et al., 2002a). Rac/cdc42 could provide a link between K-Ras and JNK signaling. Other possible downstream targets of Ras exist, including p38 and $\mathrm{PI}_{3} \mathrm{~K}$. However we have found that relatively high concentrations of inhibitors of these pathways did not re- 


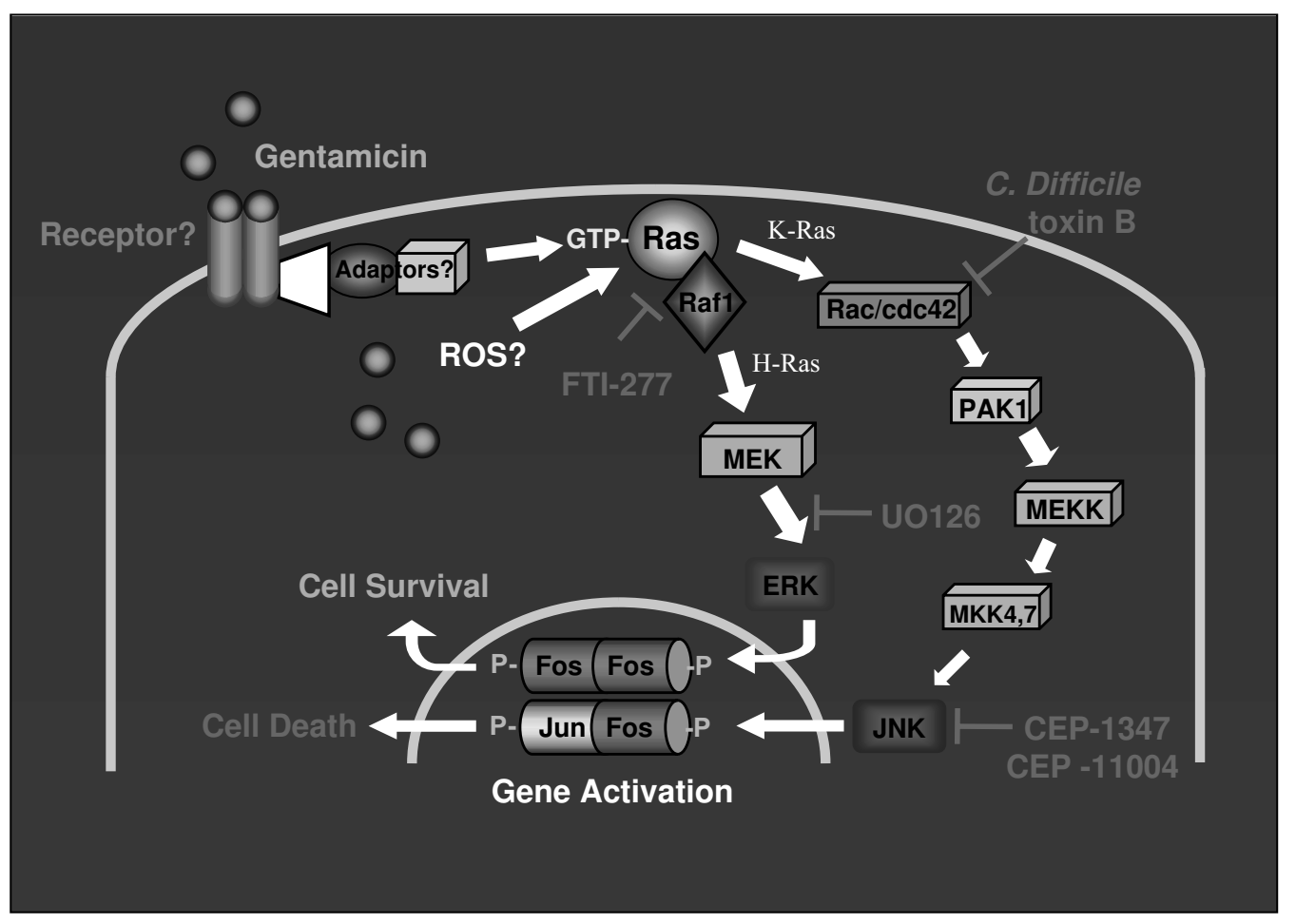

Fig. 5. A simplified model of signal transduction in gentamicin-induced $\mathrm{HC}$ damage, based on the results of this and other studies. The mode of initial interaction between the $\mathrm{HC}$ and gentamicin is not known. It may include a receptor, possibly with adaptor molecules leading to Ras activation, and/or entry of gentamicin into the cell followed by generation of reactive oxygen species (ROS) that activate Ras. Immediate activation of H-Ras, blocked by low dosages of FTI-277, leads to MEK/ERK mediation of cell survival, which in turn can be blocked by UO126. Prolonged activation of K-Ras, blocked by high dosages of FTI-277, leads to activation of Rac/cdc42, which can be inhibited by $C$. difficile Toxin B. Through intermediaries this activates JNK, which can be blocked by CEP-1423 or CEP 11003, leading to cJun phosphorylation and cell death.

duce gentamicin ototoxicity in our model system (data not shown).

A model for Ras activity in the gentamicin-exposed $\mathrm{OHC}$ can be inferred from our data and from the results of others (Fig. 5). In this model, initial ototoxin exposure activates $\mathrm{H}$-Ras, which then promotes $\mathrm{HC}$ survival through increased activation of MEK and the ERK MAPK. Thus, inhibition of H-Ras with low concentrations of FTI-277, or inhibition of MEK with UO126 enhances OHC death. Prolonged ototoxin exposure activates K-Ras, which promotes $\mathrm{HC}$ death via increased activity of JNK. Thus, inhibition of K-Ras with high concentrations of FTI-277, inhibition of Rac/cdc42 (Bodmer et al., 2002b) or inhibition of JNK (Pirvola et al., 2000; Bodmer et al., 2002b) can protect HCs from aminoglycoside exposure. The observation that highdose $\mathrm{FTI}-277$ decreases c-Jun phosphorylation in HCs due to gentamicin exposure is consistent with this interpretation.

As noted above, Ras has been shown to have variable functions depending on the environmental and genetic conditions of a cell. Ras is not alone in having variable functions. Dual functions for the regulation of cell survival, proliferation, differentiation or apoptosis have been shown for c-Myc (Evan and Littlewood, 1998), and c-Fos (Colotta et al., 1992). The evidence in this study points toward Ras playing roles both in $\mathrm{HC}$ survival and cell death.
Acknowledgements-The study was supported by grants from the NIHINIDCD (R01 DC 00139), the Deutsche Forschungsgemeinschaft (DFG) and the Research Service of the VA.

\section{REFERENCES}

Alessi DR, Cuenda A, Cohen P, Dudley DT, Saltiel AR (1995) PD 098059 is a specific inhibitor of the activation of mitogen-activated protein kinase in vitro and in vivo. J Biol Chem 270:27489-27494.

Aletsee C, Beros A, Mullen L, Palacios C, Pak K, Dazert S, Ryan AF (2001) Ras/MEK but not p38 signaling mediates neurite extension from spiral ganglion neurons. J Assoc Res Otolaryngol 2:377-387.

Andersson L, Porath J (1986) Isolation of phosphoproteins by immobilized metal $\left(\mathrm{Fe}^{3+}\right)$ affinity chromatography. Anal Biochem 154: $250-254$

Bagrodia S, Taylor SJ, Creasy CL, Chernoff J, Cerione RA (1995) Identification of a mouse p21Cdc42/Rac activated kinase. J Biol Chem 270:22731-22737.

Basu A, Modak MJ (1987) An affinity labeling of ras p21 protein and its use in the identification of ras p21 in cellular and tissue extracts. J Biol Chem 262:2369-2373.

Basu S, Bayoumy S, Zhang Y, Lozano J, Kolesnick R (1998) BAD enables ceramide to signal apoptosis via Ras and Raf-1. J Biol Chem 273:30419-30426.

Bodmer D, Brors D, Pak K, Gloddek B, Ryan AF (2002a) Rescue of auditory hair cells from aminoglycoside toxicity by Clostridium difficile toxin B, an inhibitor of the small GTPases Rho/Rac/Cdc42. Hear Res 172:81-86.

Bodmer D, Brors D, Bodmer M, Ryan AF (2002b) Rescue of auditory hair cells from otoxicity by CEP-11004, an inhibitor of the JNK signaling pathway. Laryngorhinootologie 81:853-856. 
Burke EP, Gerthoffer WT, Sanders KM, Publicover NG (1996) Wortmannin inhibits contraction without altering electrical activity in canine gastric smooth muscle. Am J Physiol 270:C1405-1412.

Casey PJ, Solski PA, Der CJ, Buss JE (1989) p21ras is modified by a farnesyl isoprenoid. Proc Natl Acad Sci USA 86:8323-8327.

Chang L, Karin M (2001) Mammalian MAP kinase signalling cascades. Nature 410:37-40.

Colotta F, Polentarutti N, Sironi M, Mantovani A (1992) Expression and involvement of c-fos and c-jun protooncogenes in programmed cell death induced by growth factor deprivation in lymphoid cell lines. J Biol Chem 267:18278-18283.

Deora AA, Win T, Vanhaesebroeck B, Lander HM (1998) A redoxtriggered ras-effector interaction: recruitment of phosphatidylinositol 3'-kinase to Ras by redox stress. J Biol Chem 273:2992329928.

Ding DL, Wang J, Salvi R, Henderson D, Hu BH, McFadden SL, Mueller M (1999) Selective loss of inner hair cells and type-I ganglion neurons in carboplatin-treated chinchillas: mechanisms of damage and protection. Ann NY Acad Sci 884:152-170.

Esteban LM, Vicario-Abejon C, Fernandez-Salguero P, FernandezMedarde A, Swaminathan N, Yienger K, Lopez E, Malumbres M, McKay R, Ward JM, Pellicer A, Santos E (2001) Targeted genomic disruption of $\mathrm{H}$-ras and $\mathrm{N}$-ras, individually or in combination, reveals the dispensability of both loci for mouse growth and development. Mol Cell Biol 21:1444-1452.

Evan G, Littlewood T (1998) A matter of life and cell death. Science 281:1317-1322.

Eyers PA, Craxton M, Morrice N, Cohen P, Goedert M (1998) Conversion of SB 203580-insensitive MAP kinase family members to drug-sensitive forms by a single amino-acid substitution. Chem Biol 5:321-328.

Huang T, Cheng AG, Stupak H, Liu W, Kim A, Staecker H, Lefebvre PP, Malgrange B, Kopke R, Moonen G, Van De Water TR (2000) Oxidative stress-induced apoptosis of cochlear sensory cells: otoprotective strategies. Int J Dev Neurosci 18:259-270.

Humpf HU, Schmelz EM, Meredith FI, Vesper H, Vales TR, Wang E, Menaldino DS, Liotta DC, Merrill AH Jr (1998) Acylation of naturally occurring and synthetic 1-deoxysphinganines by ceramide synthase: formation of $\mathrm{N}$-palmitoyl-aminopentol produces a toxic metabolite of hydrolyzed fumonisin, AP1, and a new category of ceramide synthase inhibitor. J Biol Chem 273:19060-19064.

Jo H, Cha BY, Davis HW, McDonald JM (1992) Identification, partial purification, and characterization of two guanosine triphosphatebinding proteins associated with insulin receptors. Endocrinology 131:2855-2862.

Johnson L, Greenbaum D, Cichowski K, Mercer K, Murphy E, Schmitt E, Bronson RT, Umanoff H, Edelmann W, Kucherlapati R, Jacks T (1997) K-ras is an essential gene in the mouse with partial functional overlap with N-ras. Genes Dev 11:2468-2481.

Joneson T, Bar-Sagi D (1999) Suppression of Ras-induced apoptosis by the Rac GTPase. Mol Cell Biol 19:5892-5901.

Karas M, Hillenkamp F (1988) Laser desorption ionization of proteins with molecular masses exceeding 10,000 daltons. Anal Chem 60: 2299-2301.

Kharbanda S, Saxena S, Yoshida K, Pandey P, Kaneki M, Wang Q, Cheng K, Chen YN, Campbell A, Sudha T, Yuan ZM, Narula J, Weichselbaum R, Nalin C, Kufe D (2000) Translocation of SAPK/ JNK to mitochondria and interaction with $\mathrm{Bcl}-\mathrm{x}(\mathrm{L})$ in response to DNA damage. J Biol Chem 275:322-327.

Koera K, Nakamura K, Nakao K, Miyoshi J, Toyoshima K, Hatta T, Otani H, Aiba A, Katsuki M (1997) K-ras is essential for the development of the mouse embryo. Oncogene 15:1151-1159.

Kuchan MJ, Jo H, Frangos JA (1994) Role of G proteins in shear stress-mediated nitric oxide production by endothelial cells. Am J Physiol 267:C753-758.

Lander HM, Hajjar DP, Hempstead BL, Mirza UA, Chait BT, Campbell S, Quilliam LA (1997) A molecular redox switch on p21(ras): struc- tural basis for the nitric oxide-p21(ras) interaction. J Biol Chem 272:4323-4326.

Leonard DM (1997) Ras farnesyltransferase: a new therapeutic target. J Med Chem 40:2971-2990.

Lerner EC, Qian Y, Blaskovich MA, Fossum RD, Vogt A, Sun J, Cox AD, Der CJ, Hamilton AD, Sebti SM (1995) Ras CAAX peptidomimetic FTI-277 selectively blocks oncogenic Ras signaling by inducing cytoplasmic accumulation of inactive Ras-Raf complexes. J Biol Chem 270:26802-26806.

Low W, Dazert S, Baird A, Ryan AF (1996) Basic fibroblast growth factor (FGF-2) protects rat cochlear hair cells in organotypical culture from aminoglycoside injury. J Cell Physiol 167:443-450.

Mayo MW, Wang CY, Cogswell PC, Rogers-Graham KS, Lowe SW, Der CJ, Baldwin AS Jr (1997) Requirement of NF-kappaB activation to suppress p53-independent apoptosis induced by oncogenic Ras. Science 278:1812-1815.

McCubrey JA, May WS, Duronio V, Mufson A (2000) Serine/threonine phosphorylation in cytokine signal transduction. Leukemia 14:921.

Meiteles LZ, Raphael Y (1994) Scar formation in the vestibular sensory epithelium after aminoglycoside toxicity. Hear Res 79:26-38.

Minden A, Lin A, Claret FX, Abo A, Karin M (1995) Selective activation of the JNK signaling cascade and c-Jun transcriptional activity by the small GTPases Rac and Cdc42Hs. Cell 81:1147-1157.

Newton R, Cambridge L, Hart LA, Stevens DA, Lindsay MA, Barnes PJ (2000) The MAP kinase inhibitors, PD098059, U0126 and SB203580, inhibit IL-1beta-dependent PGE(2) release via mechanistically distinct processes. Br J Pharmacol 130:1353-1361.

Palacios SD, Kayali AG, Rivkin AZ, Aletsee C, Melhus A, Webster NJG, Pak K, Ryan AF (2002) Participation of Ras and Erk in the hyperplastic response of middle ear mucosa during bacterial otitis media. J Infect Dis 186:1761-1769.

Perez-Sala D, Rebollo A (1999) Novel aspects of Ras proteins biology: regulation and implications. Cell Death Differ 6:722-728.

Pirvola U, Xing-Qun L, Virkkala J, Saarma M, Murakata C, Camoratto AM, Walton KM, Ylikoski J (2000) Rescue of hearing, auditory hair cells, and neurons by CEP-1347/KT7515, an inhibitor of c-Jun $\mathrm{N}$-terminal kinase activation. J Neurosci 20:43-50.

Raphael Y, Athey BD, Wang Y, Lee MK, Altschuler RA (1994) F-actin, tubulin and spectrin in the organ of Corti: comparative distribution in different cell types and mammalian species. Hear Res 76:173-187.

Rausch O, Marshall CJ (1997) Tyrosine 763 of the murine granulocyte colony-stimulating factor receptor mediates Ras-dependent activation of the JNK/SAPK mitogen-activated protein kinase pathway. Mol Cell Biol 17:1170-1179.

Ryan AF (2000) Protection of auditory receptors and neurons: evidence for interactive damage. Proc Natl Acad Sci USA 97:69396940.

Schacht J (1999) Antioxidant therapy attenuates aminoglycoside-induced hearing loss. Ann NY Acad Sci 884:125-130.

Sha SH, Taylor R, Forge A, Schacht J (2001) Differential vulnerability of basal and apical hair cells is based on intrinsic susceptibility to free radicals. Hear Res 155:1-8.

Shoemaker MT, Haley BE (1993) Identification of a guanine binding domain peptide of the GTP binding site of glutamate dehydrogenase: isolation with metal-chelate affinity chromatography. Biochemistry 32:1883-1890.

Shulman A (1999) The cochleovestibular system/ototoxicity/clinical issues. Ann NY Acad Sci 884:433-436.

Slee EA, Zhu H, Chow SC, MacFarlane M, Nicholson DW, Cohen GM (1996) Benzyloxycarbonyl-Val-Ala-Asp (OMe) fluoromethylketone (Z-VAD.FMK) inhibits apoptosis by blocking the processing of CPP32. Biochem J 315:21-24.

Sobkowicz HM, Loftus JM, Slapnick SM (1993) Tissue culture of the organ of Corti. Acta Otolaryngol Suppl 502:3-36.

Thorne PR, Carlisle L, Zajic G, Schacht J, Altschuler RA (1987) Differences in the distribution of F-actin in outer hair cells along the organ of Corti. Hear Res 30:253-265. 
Ui M, Okada T, Hazeki K, Hazeki O (1995) Wortmannin as a unique probe for an intracellular signalling protein, phosphoinositide 3-kinase. Trends Biochem Sci 20:303-307.

Umanoff H, Edelmann W, Pellicer A, Kucherlapati R (1995) The murine $\mathrm{N}$-ras gene is not essential for growth and development. Proc Natl Acad Sci USA 92:1709-1713.

Van de Water T, Ruben RJ (1974) Growth of the inner ear in organ culture. Ann Otol Rhinol Laryngol 83:1-16.

Walsh AB, Bar-Sagi D (2001) Differential activation of the Rac pathway by Ha-Ras and K-Ras. J Biol Chem 276:15609-15615.
Wolfman A (2001) Ras isoform-specific signaling: location, location, location. Sci STKE 2001:PE2.

Wolfman JC, Wolfman A (2000) Endogenous c-N-Ras provides a steady-state anti-apoptotic signal. J Biol Chem 275:19315-19323.

Yamamoto H, Atsuchi N, Tanaka H, Ogawa W, Abe M, Takeshita A, Ueno H (1999) Separate roles for H-Ras and Rac in signaling by transforming growth factor (TGF)-beta: H-Ras is essential for activation of MAP kinase, partially required for transcriptional activation by TGF-beta, but not required for signaling of growth suppression by TGF-beta. Eur J Biochem 264:110-119.

(Accepted 14 August 2003) 